\title{
DOES PROBLEM-BASED LEARNING IMPROVE CRITICAL THINKING SKILLS?
}

\author{
Bagus Shandy Narmaditya ${ }^{1}$, Dwi Wulandari', and Siti Rosnita Binti Sakarji ${ }^{2}$ \\ ${ }^{1}$ Faculty of Economics, Universitas Negeri Malang, Indonesia \\ ${ }^{2}$ Universiti Teknologi MARA, Melaka Malaysia \\ *Email: bagus.shandy.fe@um.ac.id
}

\begin{abstract}
The study aims to understand the implementation of Problem-Based Learning and its impact on critical thinking skills for senior high school students. The study used the lesson study approach that was conducted in four cycles. Each learning activity consisted of identifying topic, presenting the report, and evaluating the Problem-Based Learning. The subject of the study was in a Senior High School in Malang, Indonesia. The level of critical thinking refers to Structure Observed Learning Outcome (SOLO) Taxonomy, consisting of Prestructural, Unistructural, Multistructural, Relational, and Extended Abstract thinking levels. The findings in the learning process show that the students' critical thinking skills has increased. It is revealed by improving the ability to solve problems and making conclusions through critical thinking processes. The implementation of Problem-Based Learning also encourages students to think critically in the form of questioning, discussing problems and making solutions related to the employment issues, national income and economic growth in Indonesia.
\end{abstract}

\section{Keywords: Problem-Based Learning, Critical Thinking Skills, Lesson Study}

\section{APAKAH PROBLEM-BASED LEARNING DAPAT MENINGKATKAN KEMAMPUAN BERPIKIR KRITIS?}

\begin{abstract}
Abstrak: Penelitian ini bertujuan untuk mengetahui penerapan Problem-Based Learning dan pengaruhnya terhadap kemampuan berpikir kritis pada siswa sekolah menengah atas. Penelitian ini menggunakan pendekatan lesson study yang dilakukan melalui empat siklus. Setiap aktivitas pembelajaran terdiri dari mengindentifikasi permasalahan, mempresentasikan laporan kegiatan, dan mengevaluasi pelaksanaan Problem-Based Learning. Subject penelitian ini dilakukan pada sebuah Sekolah Menengah Atas di Malang, Indonesia. Tingkat kemampuan berpikir kritis siswa dalam penelitian ini mengacu pada taksonomi SOLO (Structure Observed Learning Outcome) yang meliputi prastruktural, Unistruktural, Multistruktural, Relasional, and Extended Abstract. Hasil penelitian ini menunjukkan bahwa selama proses pembelajaran, kemampuan siswa dalam berpikir kritis telah meningkat. Hal ini ditunjukkan dari peningkatan kemampuan menyelesaikan masalah dan membuat kesimpulan melalui proses berpikir kritis. Penerapan Problem-Based Learning juga mendorong siswa memiliki kemampuan berpikir kritis dalam berbagai aktivitas seperti mengajukan pertanyaan, mendiskusikan permasalahan, dan membuat solusi terkait permasalahan pengangguran, pendapatan nasional, pertumbuhan ekonomi di Indonesia.
\end{abstract}

Kata Kunci: Problem-Based Learning, Kemampuan Berpikir Kritis, Lesson Study

\section{INTRODUCTION}

Most of higher educational institutes face the problem how to transfer knowledge and how to develop and ensure professional and up-todate practical skills (Tick, 2007). Various efforts in improving the quality and process of learning in the classroom were implemented such as the use of learning models. For instance, Wulandari \& Narmaditya (2016) using simulation method to improve students learning. Futhermore, Wulandari \& Narmaditya (2017) implemented reader theater in economics course. The development of learning directed towards the student-centered leads the role of the teacher as a facilitator. Teacher-student contact time is also diminishing, making it even more imperative that students develop independent learning skills to ensure that non-contact hours are utilized effectively (Forsythe, 2002). As a consequence, the learning environment facilitates such instructional methods that require learners to actively gather and apply knowledge, therefore, 
takes another shape in which the student's, as well as the teacher's roles and duties, alter (Tick, 2007).

Student-centered approach allows student to participate actively, always challenged to have critical power, be able to analyze and solve their own problems. Critical thinking is in the family of higher order thinking skills, along with creative thinking, problem-solving, and decision-making (Facione, 1990; McBridge, 1991; Tishman \& Perkins, 1995). Some points of critical thinking are about teaching students to appropriately use concepts, principles, and procedures, thus they are capable of producing fruitful outcomes and critical judgments (Bailin et al., 1999). Additionally, critical thinking has an important implication for transfer of knowledge and application of problem-solving skills to novel situations (Garcia \& Pintrich, 1992). In this capacity, the authors assume that several advantages for students learning might be claimed for Problem-Based Learning to increase critical thinking ability.

An attempt to reach better quality of learning, teacher can utilize Problem-Based Learning (PBL) in their classroom which carried out through lesson study (Ashari et al., 2015). Lesson study is an effective way to improve teaching and learning activities in the classroom for several reasons. First, lesson study is conducted and shared by teacher based on their experiences. Second, lesson study focuses on students' activities including critical thinking skills. Therefore, lesson study can be defined as a model that teachers can do to understand the learning activities collaboratively and continuously based on mutual learning principle in enhancing learning community (Suratno, 2012). In implanting of lesson study, it consists of three main stages namely Plan, Do, and See. In plan stage, it is initiated by proposing a topic to be discussed, providing learning model to be implemented and explaining a problem that need to be solved. (Asyari et al., 2015). Further, in the stage Do, teacher model applies particular learning model based on previous plan, while the other teachers and lecturers play role as observers. During learning process, observers need to capture students' activity in the classroom. The next step in the lesson study is stage See. In this stage, teacher model and observers propose their experience and observation to discuss and promote an attempt in improving teaching and learning

Problem-Based Learning is teaching and learning model that provide contextual problems to the classroom, by this way the teacher may stimulate students to learn (Sutirman, 2013). Although the problems or tasks, may not always have a solution, Problem-Based Learning nevertheless explains a rich learning environment in which students identify what needs to be studied and learned from examining the problems confronted (Gibbs, 1992; Forsythe, 2002). There are four-five types of problems that can be applied in Problem-Based Learning courses. These are case studies, simulations, role-playings, the use of ill-structured problems that is a problem with uncertained strategies or multiple solutions and task-based or projectbased problems. These types can all be solved in group team-work or workgroups (Tick, 2007).

Problem-Based Learning is a teaching and learning model that present many authentic problems and meaningful to the students (Arends, 2015). Teaching and learning process using Problem-Based Learning challenges students to learn, to work in group and to look for the solution in the contextual problem. Teaching and learning process is directed to student in order to develop student's ability in making solutions systematically. The advantages for students learning are claimed for Problem-Based Learning to increase critical thinking ability (Masek \& Yamin, 2011).

For an assessment of, particularly when compared with conventional lecture-based teaching; 1) Problem-Based Learning fosters a deeper approach to learning; 2) Problem-Based Learning promotes more versatile studying methods and Problem-Based Learning students are more likely to use the library and library resources to study; 3) Problem-Based Learning develops greater knowledge retention and recall skills; 4) students tend to exhibit stronger knowledge application skills; 5) From a teacher perspective, Problem-Based Learning appears to be a very satisfying method of teaching (Forsythe, 2002). Moreover, Saguni (2013), remarked that Problem-Based Learning method provides higher problem solved ability compared to the jigsaw type cooperative learning method and lecturing method. 
Ineconomicscourse, manystudies provided that Problem-Based Learning is an effective method in improving students' achievement and motivation (Supandi, 2016; Ibrahim, Suyuti, \& Nadjamuddin, 2017; Sari, 2017; Narmaditya, Winarning, \& Wulandari, 2017a). In the other subject, studies investigated the implementation of Problem-Based showed varied results (Morales-Mann \& Kaitell, 2001; Galant, Frenay \& Raucent, 2012; Harun et al., 2012; Marzuki \& Basariah, 2017; Retnowati, Fathoni, \& Chen, 2018). Harun, Yusof, Jamaludin \& Hasan (2012) applied Problem-Based Learning in the classroom and it affected to students' motivation in teaching and learning. The students also became more involved in learning and become more creative and critical (Morales-Mann \& Kaitell, 2001; Galand et al., 2012). Marzuki \& Basariah (2017), mentioned that problem based learning significantly affects to student's critical thinking ability and self-discipline in the civic education. In addition, study by Retnowati et al. (2018) proposed that problem based learning is expected more effective for grouping strategies than individual instruction.

Numerous studies mentioned mainly focused on students' motivation, achievement and creative thinking skills but few number of research conducted points on critical thinking skills particularly in the economics course. First, the economics subject highly related to the complex world that make difficult to be understood. Moreover, students can play role as economist both as policy advisor and scientist. Therefore, this study examines the implementation of Problem-Based Learning in economics course to overcome difficult issues in economics. Moreover, it provides the implementation of lesson study in senior high school and how Problem-based learning affects to the students' critical thinking ability.

\section{METHOD}

This study applied qualitative descriptive approach. The research was conducted in four cycles through Lesson Study which consists of three main stage namely Plan, Do and See. In the stage, the researchers employ six experts in the field including Professor in economics education and economics teachers in a Senior High School in Malang, Indonesia. One of the teachers took the role as the teacher model and the others were the observers. Stage do consists of two main activities namely conducting classroom lesson based on previous proposed lesson plan and observing during learning process by observers. In See stage, reflection on learning outcomes is conducted in accordance with the implementation of lesson study activities and analyzing the overall learning that is done. At this stage jointly implemented by all the components that are present both groups of subject teachers, lecturers and observers, because the results of discussion and analysis can be used as input to improve or revise the next lesson.

A class of students in the participated school was the subject of the research. They were learning about several economics topics covered in the national curriculum used by the school. The topics were unemployment, national income and economic growth, and studied by using Council for Economics Education instrument (CEE, 2009). The data collection tool uses observation sheets, field note sheets, test, questionnaires, and documentation.

The tool that we employed to understand the students' critical thinking is an essay test which consists of their ability to have an argument, to evaluate, to state problems, to deduce, and to induce (Benjamin et al., 2016). The Structure Observed Learning Outcome (SOLO) Taxonomy was applied in order to measure students' ability in solving a problem that contains five phases namely Prestructural, Unistructural, Multistructural, Relational, and Extended Abstract. It was started from the lowest level to the advanced thinking levels (Biggs, 1995). In this research, the data on the learning process was conducted through Lesson Study from the observation sheet (See Figure 1).

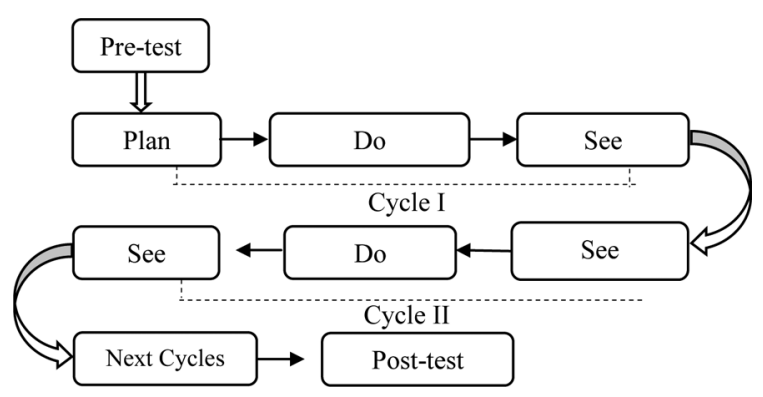

Figure 1. Research Design

For further analysis, the students' critical thinking data that were collected from pre-test and post-test and analyzed using descriptive 
method. The data of the learning process were obtained from an observation sheet during the implementation of Lesson Study. In more specifically, students were given problem in a particular topic consisted of five essay questions like providing what factors affecting unemployment in Indonesia, what the most factors affecting unemployment, what the easiest and hardest problem to be solved, and providing solution when the act as policy advisor. All of their answers should be provided by the data and deeply analysis. The problem given to the group after teacher model proposes explanation related to the topic. Furthermore, it was analyzed by comparing the average test result using explained criteria in table 1.

Table 1. Criteria of critical thinking skills
Table 1 shows information about the criteria in understanding students' critical thinking skills. In general, students' ability in thinking critically are divided into five categories which have different score. Specifically, when student answer essay questions by providing more solution, explaining great argument, illustrating in systematic language clearly, they will achieve the highest point. In contrast, when student cannot provide solution for given problem, cannot state the problem and cannot explain in correct answer, they will receive the zero point.

\begin{tabular}{cl}
\hline Score & \multicolumn{1}{c}{ Indicators } \\
\hline 4 & $\begin{array}{l}\text { Students propose a solution, explain an argument, or state problems referring to the particular given issue. Further, } \\
\text { students have more relevant answer or idea in acquaintance with received problems and several facts to provide } \\
\text { a sufficient explanation and interpret in a comprehensive, coherence and concise language. }\end{array}$ \\
3 & $\begin{array}{l}\text { Students propose a solution, explain an argument, or state problems referring to the particular given issue in the } \\
\text { assignment. Students could provide more solution or idea with several relevant examples. Moreover, students } \\
\text { also explain their work in clearly language. }\end{array}$ \\
2 & $\begin{array}{l}\text { Students propose a solution, explain an argument, or state problems referring to the particular given issue in the } \\
\text { assignment then they are provide in a systematic language. }\end{array}$ \\
1 & $\begin{array}{l}\text { Students propose a solution, explain an argument, or state problems referring to the particular given issue in the } \\
\text { assignment but they are cannot to make a connection between reveived information well and cannot provide their } \\
\text { work properly. } \\
\text { Students propose a solution, explain an argument, or state problems referring to the particular given issue in the } \\
\text { assignment or they provide a wrong answer. }\end{array}$ \\
\end{tabular}

Source: adapted by Asyari et al., (2015)

\section{FINDINGS AND DISCUSSION}

Learning Process on Problem-Based
Learning

The learning activities through lesson study were applied in four cycles using ProblemBased Learning. The learning stages consisted of identiying topics and Problem, organizing the students to learn in groups, planning the tasks, preparing a report, developing and presenting the report, and also analyzing and evaluating the problem-solving activity. In more detail, the learning action using Problem-Based Learning are illustrated in the following figure (See figure 2).

Inthefirstmeeting, students were organized into small groups that work independently from other groups throughout the teaching term. Since we usually designed tasks that comprise different components, we employ groups of six to eight students. Each group received a topic related to unemployment, national income or economic growth. Moreover, teacher model gave some problems to the students, for example, told them about fourteen causes of unemployment in Indonesia, types of unemployment in Indonesia, policies related to unemployment in Indonesia. Further, teacher model asked students to collect data, made an analysis and decided to agree or disagree to the statement we made previously. Students also need to observe at the unemployment in their areas and compare to the other region investigated by their classmates. Related to the national income, teacher model also provided the students to collect time series data, propose the idea that consumption makes up the biggest part of national income and the government should increase consumption of the people. 
The next section was challenging the students to agree or disagree and connect their answer with real data, news and theories. They need to conduct a research through the internet sources related to this topic. Last for the growth rate, the teacher model proposed the mainidea that higher economic growth was happened in a more open economy with market economic system. Further, students provided their ideas toward the critical unemployment issues in Indonesia, how to measure unemployment, how to differentiate the unemployment categories and will there ever be a zero rate of unemployment. In the other hand, at the topic of National Income, students were asked to discuss how to distinguished Gross Domestic Products and Gross National Products and what are the components and how to measure national income with three types of methods (production, expenditure and income approach).

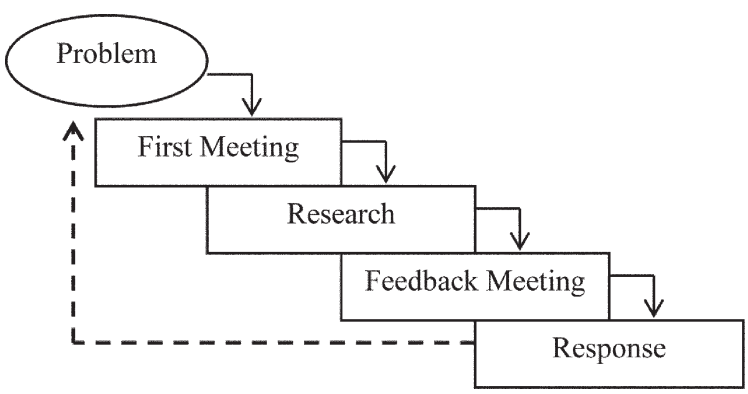

Figure 2: Learning stages using ProblemBased Learning

Source: Forsythe (2002)

Moreover, we continued the discussion of economic growth and students learned a lot about what makes some countries grow more than other countries and what happened in the transition economy countries. Between the first and feedback meetings associated with a particular problem or task, group members undertake the study task allocated to them at the first meeting. Members report back the results of their allocated research activity to the group (after the task recorder has reminded the group of individual responsibilities). Each group discuss by using resources from relevant books and data from the official websites to provide ideas in overcoming problem related unemployment, national income and economic growth in Indonesia. Students found this is very interesting and they can understand about the macro variables very well with this kind of method. Using all of the information gathered, the group formulates responses to the problems. They did a brainstorming activity and try to find a better example related to all three topics related to macroeconomics.

On the unemployment topics, teacher model also asked the students to give a real example about what really happened in their areas because students come from different areas that have dissimilar problems and local policies. The discussion becomes very interesting since they are talking about their own areas so everybody can learn about other things that not happened in their areas. Related to national income, the students make analysis to the real data in Indonesia for the past ten years. The national income is having differences year by year and students need to know what are the causes of this phenomenon. Before they can decide, they also need to look at the national income data thoroughly so they understand what variables contribute to the increase or decrease of the national income. After that, we compared economics growth of Indonesia and other countries especially countries in transition economy, an economy that is moving towards more open economy or market economy.

\section{Learning Process Through Lesson Study}

The implementation of lesson study started from the plan stage of discussing the lesson plan together with observed for advice and feedback. In the plan, prepare for lesson plan material about unemployment, national income and economic growth with a learning sheet, an instrument for Lesson Study. The prepared format includes the observation format and order of implementation Lesson study. This format is structured to document lesson study activities so that accurate reflection can be conducted. In addition, lesson study team members also plan and develop completely learning tools and instruments for the purpose of the implementation phase (plan), namely the preparation of lesson plans, material handouts, Student Activity Sheets, observation sheet of teacher activities and students in Problem-based learning.

In the next stage is implementation (do) lesson plan before. The preliminary in this stage suggest a teacher model giving perception, motivation, and explain the learning model. The implementation of learning is divided into five 
activities namely the initial activity core activities consisting of stages of student orientation to the problem, organizing students to learn; guiding individual and group investigation, presenting the work, and also analyzing and evaluate the learning process; and the final activities. This is in accordance with the lesson plan with the problem-based learning model, with the help of three members of the lesson study team will observe activity undertaken by teachers and students in the learning process. At the See stage, reflection on learning outcomes is conducted in accordance with the implementation of lesson study activities and analyzing the overall learning that is done. At this stage jointly implemented by all the components that are present both groups of subject teachers, lecturers and observers, because the results of discussion and analysis can be used as input to improve or revise the next lesson.

The implementation of Problem-Based Learning through lesson study are going quite well, but we also found the students were still less active in group conversations and class discussions. Students are still less familiar with group learning especially with groups that are not in accordance with the wishes of students. Students are still inclined to work individually and ask for immediate difficulties to the teacher instead of being discussed first with group members.

Another issue is misconception about the learning materials. The concepts that are hard to be understood by students are types of unemployment in Indonesia since it has a slightly difference with the definition of unemployment in other country such as The United States of America. Misconception happened because of different definition of unemployment in each countries and dissimilar way to measure unemployment so sometimes the same rate of unemployment will implicate to a different way to solve the problem because of the diferrent component of unemployment definition and types. However, it can be solved in the next cycle by proposing the students to observe at the real data, phenomenon and conducting a small research through the data and news in the internet and discuss the differences in the classroom. By discussing and brainstorming, the source of missconception was easier to be found and solved.
Related to national income, sometimes the students find it hard to distinguished the difference of each methods to measure Gross Domestic Product (GDP) particularly in acquaintance with production methods. The lack of understanding also occurred in economic growth topic. Some of these students realize that it hard to comprehend the stages of growth in many countries. By applying Problem-Based Learning method, these problems can be overcome in the next cycle. In the other hand, the brainstorming was the nicest part for students. This is understandable because they were really engaged in the discussion. The teachers remarked that before the method applied, the students were less critically thinking and not engaging as much as this time. Most of the economics teaching in Senior High School were only passing knowledge from teachers to students and not asking them to really think about the topics.

After the method implemented instead of only transfering knowledge, the teacher proposed questions that makes them think and use their critical thinking skill, and also use their ability to investigate phenomenon in their country and their areas. Students were provided questions such as why in a under develop countries like indonesia which has experienced an upward trend in economic growth still face inequality?. Having questions to be investigated, apparantly changed their ways of learning and challenged them to really be critical of the macroeconomics phenomenon in Indonesia. They also found connections between variables and what happened during every business cycle in Indonesia at every era.

After finished all cycles, studens were also given questionnaires about their perception toward the implementation Problem-Based Learning in their classroom. The findings of this study remarked that students find this method is very interesting because they get to learn about the real economy instead of only talking about theories that were harder to imagine. This method also escalade their presentation and debating skill. Some students find it hard to talk in front of the public because they feel shy to talk in front of many people. However, after participating in this discussion, they learn how to overcome their nervousness in front of the class. In debating, they also find it very interesting to be critical of the findings of other groups. Students become very 
active in class and understand more about some topics that previously hard to follow. The data on the learning process through Lesson Study were provided from an observation sheet.

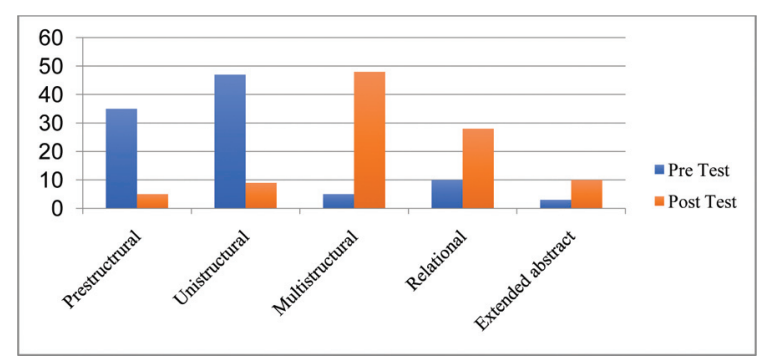

Figure 3. Mean Scores of Critical Thinking Skills in Pre-Test and Post-Test

Figure 3 provides information about the differences critical thinking skills of students by comparing pre-test and post-test. In general, large number of students previously categorized as prestructural and unistructural, whilst only small number was categorized as another three namely multistructural, relational and extended abstract. In more detail, the pre-test result of the students' critical thinking showed about 35 per cent of students was categorized in prestructural stage and 47 per cent of students were in unistructural stage. However, only approximately 5 per cent of students were categorized in multistructural phase, whilst 9.70 percent of them are in relation and none 3 per cent of them in extended abstract thinking stages.

After Problem-Based Learning implemented through lesson study, it showed a dramatically improvement in students' critical thinking skills. Based on figure 3, it explained that as much as 5 per cent of students are in prestructural stage, while 9 per cent of them are in unistructural stage. Another result showed that almost a half of students categorized in multistructural phase, 28 per cent in relational stage and 10 per cent in extended abstract, respectively.

\section{DISCUSSION}

\section{Impact Problem-Based Learning on Critical Thinking Skills}

To understand the effect of Problem-Based Learning and Critical Thinking skills, this study applied to Structure Observed Learning Outcome Taxonomy or SOLO Taxonomy which consisting of five stages of critical thinking skills namely Prestructural, Unistructural, Multistructural,
Relational, and Extended Abstract thinking levels (Biggs, 1995). It is revealed that by applying Problem-Based Learning in the classroom improves the teaching and learning remarkably. This statement is also supported by numerous prior studies such as Hsu (2014), Narmaditya et al. (2017a) and Nafisah \& Suyanto (2014). Problem is the main focus of teaching and learning that will happen through problem-solving activities. Declarative knowledge and skills that are gained through critical thinking skills will be applied to solve a problem (Zabit, 2010).

In the research, teacher proposed problems related to unemployment, national income and economic growth respectively. The topics were chosen to be applied in Problem-Based Learning because these topics were categorized as difficult concepts in economics. Based on findings, some students feel that unemployment was the crucial issue to be understood. Previously, students feel hard to distinguish three different types of unemployment namely structural, frictional and cyclical that make them categorized in prestructural and multistructural. Pre-structural thinking stage is the lowest stage of thinking, in whichastudentcannotunderstand properlytoward the problem given and tends to not provided their answers. Further, they are not be able to manage well an information, misunderstood concept, and the task given is not suitable to the assignment done. pre-structural level students do not yet understand the knowledge they are supposed to learn, probably because they have not been taught it yet. The condition at this level, students do not understand how to gather information about the ideas, how to organize it in relation to other ideas, and do not get the point of the idea at all (Goff et al., 2015).

Another topic given in the other meeting was national income. For this topic, students experienced a challenge in providing what is the circular flow in national income and how it impacts to the economic welfare. This study found that almost a half percentages of students were categorized at unistructural stage. Most students answered the questions related to unemployment and national income only referring to books without proposing greater argument.

Unistructural thinking stage is marked by students' ability in managing only less than a half from whole information and tasks received. Moreover, students' ability showed by solving 
Table 3. Dimension of SOLO Taxonomy

\begin{tabular}{|c|c|c|c|c|}
\hline \multirow[b]{2}{*}{ Prestructural } & \multicolumn{2}{|c|}{ SURFACE LEARNING } & \multicolumn{2}{|c|}{ DEEP LEARNING } \\
\hline & Unistructural & Multistructural & Relational & Extended Abstract \\
\hline \multicolumn{5}{|c|}{ 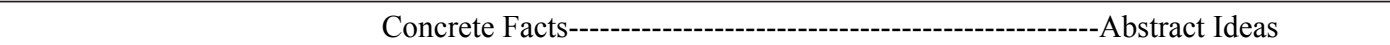 } \\
\hline \multicolumn{5}{|c|}{ Few Organizing dimensions----------------Many Organizing Dimensions } \\
\hline \multicolumn{5}{|c|}{ Minimal Consistency------------------------------Maximal Consistency } \\
\hline \multicolumn{5}{|c|}{ No use of organizing principles---Complex use of organizing principles } \\
\hline \multicolumn{5}{|c|}{ Low cognitive capacity--------High cognitive capacity } \\
\hline \multicolumn{5}{|c|}{ No Relationship-----------Multiple relationship } \\
\hline \multicolumn{5}{|c|}{ High need for closure-- } \\
\hline
\end{tabular}

Source: Goff et al. (2015)

simple problem proposed during teaching and learning. Based on findings, it showed that only small percentages students were categorized as multistructural stage. This phase is evidenced by adapting more than one information but they cannot provide the relationship each information. On the other word, in this stage, students could use better information to solve particular problem even though they cannot propose a conclusion by using all information.

Meanwhile, Relational thinking illustrates better critical thinking ability. It revealed by better abilities in several learning activities such as understanding the topic, analyzing given information, making a relationship between received information, explaining argument, providing so much better conclusion. For the case of unemployment, students proposed better list from the lowest to highest factors affecting unemployment rate in Indonesia. They used several data from the internet and books to propose their ideas in solving the problem. Furthermore, students already provide greater explanation in proposing argument related unemployment problem in Indonesia. Students who are categorized relational thinking rose almost doubled compared to pre-test.

Even though only small percentages students that having extended abstract thinking stage, it rose dramatically comprared to previous test. In the other word, students prepared well their argument related to the topic and proposing great idea to solve the unemployment problem in Indonesia. For topic related to national income, they not only can understand the circular flow national income, but they also tried to combine some situation and it effects to the national income. In the Students who are categorized at the extended abstract thinking skills have deductive and inductive capability to make a connection between received information. Further, they also could explain properly about the given topic and provide well explanation by using several perspectives (Ashari et al., 2012). Knowledge at multistructural level is more complex than knowledge at a unistructural level, and knowledge at a relational level is more complex than knowledge at a multistructural level.

Therefore, it can be concluded that Problem-Based learning can improve the ability of critical thinking in students. The result of the study in the learning process, students' critical thinking skills increase showed by ability to solve problems and make conclusions through critical thinking processes. By giving particular problem, students will critically propose an idea to solve the problem by collecting some materials from books and the data from the internet, analyzing the collected information and proposing a way to solve the problem. Implementation of ProblemBased Learning also encourages students to think critically in the form of questioning, discussing problems and making solution related topic in the economics course (Sendaq \& Odabas, 2009; ElShaer \& Gaber, 2014; Birgili, 2015; Narmaditya et al., 2017a).

The implementation of Problem-Based Learning in this study is concluded that it can improve critical thinking skills since it was observed that students become more active and able to use their thinking ability, students are not just passive in receiving explanations submitted by teachers. It is agreed that in Problem Based Learning, students are required to actively develop their thinking skills to formulate problems and find solutions in solving problems, so as to develop their critical thinking skills capability. 


\section{CONCLUSION}

The implementation of Problem-Based Learning that was impmented in four cycles (Plan, Do, See) showed that it was facilitating critical thinking. The growth of critical thinking skill of student regarding to SOLO taxonomy appeared to increase in each level: Prestructural, Unistructural, Multistructural, Relational, and Extended Abstract. The findings of the study revealed an increased of ability to solve problems and make conclusions through critical thinking processes. of the practice of ProblemBased Learning that specifically encourages students to think critically were when the teacher provided activities during questioning, discussing problems, and making solution related to the topic in the course. Revision and reflection process that were given at the end of the learning assisted students to understand deeper and avoid misconception.

\section{REFERENCES}

Arends, R.I. (2015). Learning to Teach $\left(10^{\text {th }}\right.$ Edition). New York: Mc Graw-Hill Education.

Asyari, M., Mudhar, M. H. I. A., Susilo, H., \& Ibrohim, I. (2015). Improving critical thinking skills through the integration of problem-based learning and group investigation. International Journal for Lesson and Learning Studies, 5(1), 36-44. https://doi.org/10.1108/IJLLS-10-20140042

Bailin, S., Case, R., Coombs, J. R., \& Daniels, L.B. (1999). Conceptualizing critical thinking. Journal of Curriculum Studies, 31(3), 285-302. https://doi. org/10.1080/002202799183133

Biggs, J. (1995). Assessing for learning: Some dimensions underlying new approaches to educational assessment. The Alberta Journal of Educational Research, 41(1), $1-17$.

Birgili, B. (2015). Creative and critical thinking skills in problem-based learning environments. Journal of Gifted Education and Creativity, 2(2), 71-80. https://doi. org/10.18200/JGEDC.2015214253
Choi, H. (2004). The effect of PBL on the meta-cognition, critical thinking, and problem solving process of nursing students. Taehan Kanho Hakhoe Chi, 34(5), 712-721. https://doi.org/10.4040/ jkan.2004.34.5.712

Council for Economic Education. (2009). The market never stop to move. New York, NY.

El-Shaer, A., \& Gaber, H. (2014). Impact of problem-based learning on students' critical thinking dispositions, knowlegde acquisition and retention. Journal of Education and Practice, 5(14), 75-85.

Benjamin, R., Klein, S., Steedle, J., Zahner, D., Elliot, S., \& Patterson, D. (2016). The case of critical thinking skills and performance assessment. Council for aid to education. New York, NY.

Facione, P. A. (1990). Critical thinking: A statement of expert consensus for purposes of educational assessment and instruction. Millbrae, CA: The California Academic Press. Retrieved from https:// eric.ed.gov/?id=ED315423

Forsythe, F. (2002). Problem-Based Learning $2^{\text {nd }}$ (Revised) Edition: The Handbook For Economics Lecturer. Retrieved from https://www. economicsnetwork.ac.uk/ handbook/printable/pbl2.pdf.

Galand, B., Frenay, M., \& Raucent, B. (2012). Effectiveness of problem-based learning in Engineering education: A comparative study on three level of knowledge structure. International Journal of Engineering Education, 28(4), 939-947.

Garcia, T., \& Pintrich, P. R. (1992). Critical thinking and its relationship to motivation, learning strategies, and classroom research. The Annual Meeting of the American Phsycological Assiciation, August 14-18. Retrieved from https://eric. ed.gov/?id=ED351643 
Gibbs, G. (1992). Improving the quality of student learning. Bristol: Technical and educational services.

Harun, N. F., Yusof, K. M., Jamaludin, M. Z., \& Hassan, S. A. H. S. (2012). Motivation in problem-based learning implementation. Procedia-Social and Behavioral Sciences, 56, 233-242. https://doi: 10.1016/j. sbspro.2012.09.650

Hsu, C. (2014). The study of adoption problem based learning in normal scale class course design. International Conference on Educational Technologies 2014, 3-10.

Ibrahim, A. S. E., Suyuti., \& Nadjamuddin, L. (2017). Pengaruh problem-based terhadap hasil belajar mata pelajaran ekonomi pada siswa SMA Negeri 1 Palu. Jurnal Katalogis, 5(4), 9-20. https://doi. org/10.22487/j23022019,2017.v5.i4.8914

Marzuki, M., \& Basariah, B. (2017). The influence of problem-based learning and project citizen model in the civic education learning on student's critical thinking ability and self discipline. Cakrawala Pendidikan, 36(3), 382-400. http://dx.doi. org/10.21831/cp.v36i3.14675

Masek, A., \& Yamin, S. (2011). The effect of problem based learning on critical thinking ability: A theoretical and empirical review. International Review of Social Sciences and Humanities, 2(1), 215-221.

McBride, R. E. (1991). Critical thinking: an overview with implications for physical education. Journal of Physical Education, Reacreation and Dance, 69(7), 112-125.

Morales-Mann, E. T., \& Kaitell, C. A. (2001). Problem-based learning in a New Canadian curriculum. Journal of Advanced Nursing, 33(1), 13-19.

Nafisah, Y. N., \& Suyanto, W. (2014). Penerapan problem-based learning untuk meningkatkan kemampuan berpikir kritis dan hasil belajar siswa. Jurnal Pendidikan
Vokasi, 14(1),125-143. http://dx.doi. org/10.21831/jpv.v4i1.2540

Narmaditya, B.S., Winarning, W., \& Wulandari, D. (2017a). Impact problem based learning on student achievement in Economics course. Classroom Action Research Journal, 1(1), 1-10. http://dx.doi. org/10.17977/um013v1i12017p001

Ono, Y., \& Ferreira, J. (2010). A case study of continuing teacher professional development through lesson study in south africa. South African Journal of Education, 30, 59-74.

Goff, L., Potter, M. K., Pierre, E., Carey, T., \& Gullage, A. (2015). Learning Outcomes Assesment A Practitioner's Handbook. Centre for Teaching and Learning, University of Windsor. Retrieved from https://scholar.uwindsor.ca/ctlreports/6

Saguni, F. (2013). The effectiveness of the problem-based learning, the jigsaw type cooperative learning, and lecturing methods as problem solving in the instructional planning course. Cakrawala Pendidikan, 37(2), 207-218. http://dx.doi. org/10.21831/cp.v0i2.1478

Sari, M. R. (2017). The implementation problem-based learning to enhance activity and students learning outcome. Classroom Action Research Journal, 1(4), 168-174. https://doi.org/10.17977/ um013v1i42017p168

Sendaq, S., \& Odabas, H.F. (2009). Effect of problem-based learning course on content knowledge acquisition and critical thinking skills. Computers and Educations, 53(1), 132-141. https://doi. org/10.1016/j.compedu.2009.01.008

Sulaiman, F. (2011). The effectiveness of problem-based learning online on students' creative and critical thinking in Physics at tertiary level in Malaysia', Ph.D. Thesis. University of Wakaito. Retrieved from https://hdl.handle.net/10289/4963 
Suratno, T. (2012). Lesson study in Indonesia: an Indonesia University of Education experience. International Journal for Lesson and Learning Studies, 1(3), 196-215, https://doi. org/10.1108/20468251211256410

Sutirman. (2013). Model-Model Pembelajaran Inovatif. Jakarta: Graha Ilmu.

Retnowati, E., Fathoni, Y., \& Chen, O. (2018). Mathematics problem based solving skill acquisition: learning by problem posing or problem solving. Cakrawala Pendidikan. 37(1), 1-10. http://dx.doi.org/10.21831/ cp.v37i1.18787

Supandi. (2016). Model pembelajaran based learning, motivasi belajar dan peningkatan prestasi belajar mata pelajaran ekonomi SMA. Jurnal Penelitian dan Pendidikan IPS (JPPI), 10(3), 379-388.

Tick, A. (2007). Application of ProblemBased Learning in Classroom Activities and Multimedia. $5^{\text {th }}$ SlovakianHungarian Joint Symposium on Applied Machine Intelligence and Informatics, pp. 363-375. Retrieved from https://pdfs.semanticscholar.org/ fe8b/a7e73bd1461f2783f19b39eeeddd7b 634eb9.pdf
Tishman, S., \& Perkins, D. (1995). Critical thinking and physical education. Journal of Physical Education and Recreational Dance, 66(6), 24-30. https://doi.org/10.10 80/00336297.2004.10491830

Wulandari, D., \& Narmaditya, B. S. (2017). Readers theater as a tool to understand difficult concept in economics. International Education Studies, 10(5), 144. https://doi.org/10.5539/ies. v10n5p144

Wulandari, D., \& Narmaditya, B.S. (2016). Using Simulation Methods to Improve Student Learning. Conference Proceedings 2nd International Conference on Education 2016. Bangkok-Thailand. https://doi. org/10.17501/icedu.2016.1101

Zabit, M.N.M. (2010). Problem-based learning on students' critical thinking skills in teaching business education in malaysia: a literature review. American Journal of Business Education, 3(6), 19-32. Retrieved from https://files.eric.ed.gov/ fulltext/EJ1058610.pdf 